\title{
ASSESSMENT OF VARIOUS STRATEGIES FOR THE PRESERVATION OF CLONAL GENETIC RESOURCES IN OIL-PALM (Elaeis guineensis JACQ.)
}

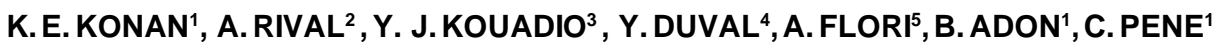 \\ and T.D.-GASSELIN ${ }^{5}$
}

${ }^{1}$ CNRA, Station de La Mé 13 BP 989 Abidjan13, Côte d'Ivoire (eugenekonank@hotmail.com)

${ }^{2}$ CIRAD Cultures Pérennes. Present Address: CSIRO Plant Industry, GPO Box 1600, ACT 2601 Canberra, Australia

${ }^{3}$ UFR des Sciences de la Nature, Université Abobo-Adjamé, 02 BP 801, Abidjan 02, Côte d'Ivoire

${ }^{4}$ IRD, UMR1098, BP 5045, 34032 Montpellier Cedex 01, France

${ }^{5}$ CIRAD Cultures Pérennes, UPR28, TA 80/03, Avenue Agropolis, 34398 Montpellier Cedex5 - France

\begin{abstract}
Three different approaches for the preservation of oil palm (Elaeis guineensis Jacq.) clonal genetic resources and their impacts on the induction of the « mantled » somaclonal variation were assessed. In vitro long term preservation of somatic embryos stock-cultures was studied : after a 5 year cultivation period, $75 \%$ of clonal lines were still normal. Between 8 and 13 years of embryo cultures, half of the considered clonal lines were found to be « mantled ». Finally, $40 \%$ were found to be normal over 15 years of in vitro conservation. Clonal conformity of ramets resulting from the re-cloning of somaplants depended, on one hand, on the floral status of the mother plant at the time of sampling and, on the other hand, on its origin. Re-cloning of abnormal regenerants led, in all cases, to $100 \%$ abnormal offspring. The age of the ramet used as mother palm at the time of sampling was found to be critical for true-to-type regeneration. There is a high risk of obtaining variant regenerant palms if the clonal mother palm is sampled at nursery stage. Field observations carried out on palms originating from somatic embryos cryopreserved at $-196{ }^{\circ} \mathrm{C}$ showed floral conformity rates comparable to those obtained from standard not-cryopreserved clonal palms, for 6 out of the 8 clonal lines studied. From the 2 remaining clonal lines, a few regenerant palms originating from standard batch were found to be « mantled », whereas those resulting from cryopreserved embryos were all normal. The assumption of changes in levels of genomic DNA methylation during preservation was discussed, together with the capacity of our cryopreservation protocol to select embryogenic cells which were only suited to trueto-type regeneration.
\end{abstract}

Key words : In situ preservation, « mantled » floral abnormality, somaclonal variation, somatic embryogenesis, oil palm, Côte d'Ivoire

\section{RESUME}

EVALUATION DE DIFFERENTES STRATEGIES DE CONSERVATION DES RESSOURCES GENETIQUES CLONALES DE PALMIER A HUILE (Elaeis guineensis JACQ.)

Trois approches de conservation des ressources génétiques clonales de palmier à huile (Elaeis guineensis Jacq.) ont été testées et leurs incidences sur l'induction de la variation somaclonale " mantled » ont été évaluées. La conservation in vitro à long terme des souches d'embryons somatiques a montré qu'après 5 ans de culture, $75 \%$ des clones étaient encore normaux. Entre 8 et 13 ans de culture, la moitié des clones a présenté des plants à floraison anormale « mantled». Finalement, $40 \%$ des clones étaient toujours normaux même après 15 ans de conservation in vitro. La conformité florale des plants issus de reclonage de vitroplants dépend, d'une part, du statut floral du palmier donneur au moment de son utilisation et, d'autre part ,de l'origine de la lignée clonale à laquelle il appartient. Le reclonage de régénérants anormaux a conduit, dans tous les cas, à $100 \%$ de descendances anormales. L'âge du vitro plant donneur au moment de son prélèvement semble être essentiel pour l'obtention d'une régénération conforme. Un 
grand risque d'obtention de régénérants variants existe si le plant utilisé est prélevé au stade pépinière. Les observations réalisées sur les palmiers issus d'embryons cryoconservés à -196 ${ }^{\circ} \mathrm{C}$ ont montré des taux de conformité florale comparables à ceux issus d'embryons témoins non congelés, pour 6 des 8 clones étudiés. Pour les 2 autres clones, quelques plants issus d'embryons témoins ont présenté la variation florale " mantled », alors que ceux issus d'embryons cryo-conservés ont tous été normaux. L'hypothèse d'une modification du niveau de méthylation de l'ADN génomique au cours de la durée de la conservation a été discutée et la capacité de notre protocole de cryoconservation à sélectionner les cellules embryogènes aptes à une régénération conforme de plants.

Mots clés : Conservation in situ, anomalie florale «mantled », variation soma clonale, embryogenèse somatique, palmier à huile, Côte d'Ivoire.

\section{INTRODUCTION}

Oil palm (Elaeis guineensis Jacq.) is a perennial oil crop cultivated in the tropical humid regions. It has been for more than 20 years, the second world source of vegetable oil after soybean (Fry, 2002). Oil palm has the highest oil yield per hectare among oleaginous crops (Corley, 2003), with some of the best recent progenies being able to reach more than $10 \mathrm{t} / \mathrm{yr} / \mathrm{ha}$ under suitable agro-ecological conditions. Nevertheless, oil palm farming is still at its early stages in terms of number of generations of improved plant material made available to farmers (DurandGasselin et al., 2002). There is indeed a huge genetic potential for oil palm, a sexually propagated allogamous species, still to be exploited. In this context, the in vitro cloning of elite palms through somatic embryogenesis has been proposed (Noiret, 1981) in order to take advantage of the high degree of variability which still resides among improved progenies.

Using this technique, the expected increase in oil production has been estimated to reach 25 to $30 \%$ (Soh, 1986, Meunier et al., 1988). These forecasts were confirmed by results from large scale field trials, carried out worldwide (DurandGasselin et al., 1993 ; Corley et al., 1995 ; Cochard et al., 1999). A number of clones were found to perform well and they constitute now the best planting material to be broadcasted to planters. Unfortunately, it was also demonstrated that the availability of somatic embryos was one of the major bottlenecks for the use of tissue culture for the large scale production of elite material (Rival et al., 1998).

Indeed, the very long period (at least 10 years) which is needed for field assessment of oil palm clonal offspring requires the in vitro conservation and propagation of somatic embryos, with a high risk of somaclonal variation and genetic/ epigenetic changes in cultures. The most important somaclonal variation described in oil palm affects organs in flowers of both sexes, resulting in a feminization of male parts. It is specific to palms originating from tissue culture and can be detected only after 2-3 years of field plantation. This abnormality has been identified for the first time in Malaysia by Corley et al. (1986) who named it « mantled », then it has been described by various authors in clonal plantings worldwide (Duval et al., 1988 ; Paranjothy et al., 1989 ; Wooi, 1990 ; DurandGasselin et al., 1993).

In most severe cases, the "mantled » abnormality may induce total sterility of palms, thus hampering the development of large scale production of clonal material. Nevertheless, it is worth noting that most of the clonal lines produced have never been abnormal and that the average impact is only $5 \%$ of regenerants in planting material (Durand-Gasselin et al., 1993 ; Konan et al., 1995). Furthermore, a constant reversion of « mantled » material towards a normal phenotype has been recorded, even in palms, which were very severely affected by somaclonal variation at the young age (Durand-Gasselin et al., 1993 ; Konan et al., 1995 ; Duval et al., 1997). Commercial production of oil palm clones through somatic embryogenesis is now integrating the risk of « mantled » variation (Corley, 2003). In parallel, molecular studies are under way, aimed at tackling this phenomenon and understanding its molecular basis (Tregear et al., 2002 ; Jaligot et al., 2000 ; Rival et al., 2003 ; Rival et Parveez, 2004).

It is thus of paramount importance to explore various methods of plant genetic resources preservation, in order to maintain the genetic stability of improved oil palm clonal germplasm.

In this work, three different strategies were investigated:

The in vitro preservation of somatic embryos as poly-embryonic cultures : following this strategy, somatic embryos are made directly available, 
at any time of the preservation process, for large scale production of microplants. The genetic stability of regenerated plants must be assessed by the continuous planting of aliquot batches at different in vitro cultivation times (DurandGasselin et al., 1993) ;

The cryopreservation of embryogenic masses in liquid nitrogen $\left(-196{ }^{\circ} \mathrm{C}\right)$ : this alternative technology has been successfully developed for oil palm (Engelmann et al., 1985 ; Dumet et al., 1993a,b ; Chabrillange et al., 2000) in the aim of improving the in vitro management of germplasm, collection and preserving genetic resources on the long term, while limiting the risks of losses by contamination and genetic instability due to the cultivation of somatic embryos on a prolonged period;

The in situ preservation as living collections in the field : somaplants can be sampled again for a second (and even third) cloning operation through somatic embryogenesis (recloning of somaplants or « ramets »). This strategy notably differs from the two others: despite its considerable cost, it enables the long term preservation in the field of valuable germplasm which can be exploited at any time for the production of new generations of somaplants.

These three different approaches (namely : preservation, cryopreservation and the re-cloning of clonal material) were studied for the preservation of oil palm clonal genetic resources and their respective impact on the induction of the « mantled » somaclonal variation has been assessed.

\section{MATERIAL AND METHODS}

\section{PLANT MATERIAL}

Plant material used in the present study was adult tenera oil palms (Elaeis guineensis Jacq.), aged 10 - 20 years at the time of field sampling for in vitro culture. These were mother palms (ortets) previously selected for their outstanding field performance from the best crosses among progeny trials planted at La Mé Research Station, Centre National de Recherche Agronomique (CNRA) in Côte d'Ivoire. The experiment aimed at assessing the stability of embryo cultures involving 20 different clonal lines. Six clonal lines were tested in a cryopreservation experiment, and the recloning procedure was implemented using 28 regenerant palms originating from 17 different clonal lines.

\section{IN VITRO CULTURE AND GENERATION OF EMBRYOGENIC LINES}

The production of oil palm somaplants followed protocols for somatic embryogenesis, which have been already described (Pannetier et al., 1981 ; Duval et al., 1995. This procedure enabled the production of Stabilised Polyembryonic Cultures (SPCS), which could be cultivated indefinitely on a hormone-free modified MS medium (Wong et al., 1996 ; Konan et al., 2005).

\section{PRESERVATION OF CLONAL GENETIC RESOURCES}

\section{In vitro preservation}

In this experiment, one single line of SPC was used per clonal line. Once a year, SPC cultures were transferred onto shoot development medium in order to produce a sizeable batch of plants. These somaplants were then acclimatized and field-planted in order to assess their performances, especially the impact of the « mantled » floral abnormality. The number of somaplants may vary from one clonal line to the other or from one year to the other, depending on laboratory constraints and nursery/field availability.

\section{Cryopreservation}

The protocols for embryo cryopreservation used in the present study were specifically developped for oil-palm by Engelmann (1985) and Dumet et al. (1993a,b). Cryopreserved material was made up of somatic embryos sampled from SPC cultures. The Dumet et al. (1993a,b) procedure cryopreservation used, combined three main steps :

Desiccation: Masses of somatic embryos (250 to $300 \mathrm{mg}_{\mathrm{FW}}$ ) were sampled from SPCs and cultivated for 7 days on a multiplication medium (Pannetier et al., 1981) supplemented with $0.75 \mathrm{M}$ sucrose, then kept for $16 \mathrm{~h}$ on silica gel (5 embryo masses per $40 \mathrm{~g}$ of silica gel) ;

Freezing : Desiccated embryo masses were transferred to sterile cryotubes then directly soaked in liquid nitrogen for at least one hour. They were then preserved indefinitely at $-196^{\circ} \mathrm{C}$ in liquid nitrogen ; 
Thawing and embryos multiplication : Cryotubes containing cryopreserved embryo masses were taken out of liquid nitrogen and rapidly soaked in a water bath at $40{ }^{\circ} \mathrm{C}$ for 2 min. Embryos were then in vitro cultivated for one week on a medium supplemented with $0.3 \mathrm{M}$ sucrose and $0.2 \mathrm{mg}^{. \mathrm{I}^{-1}} 2,4-\mathrm{D}$, then for 2 weeks on the same medium, with a lower concentration of sucrose $(0.1 \mathrm{M})$. Embryos were then transferred onto standard multiplication medium without growth regulators.

The incidence of each cryopreservation step on the conformity of regenerated plant material was assessed for each clonal line through field monitoring, performed on 3 batches of somaplants originating from 3 different embryo cultures. Each of these cultures were derived from the same original culture, but they differed from their treatments :

- Standard treatment (S) : Somatic embryos were neither desiccated nor frozen ; they were directly transferred for the production of somaplants ;

- « Desiccation Only » treatment (DO) : Somatic embryos underwent the whole desiccation treatment, but were not placed in liquid nitrogen ;

- « Desiccation-Liquid Nitrogen » treatment (DLN) : In this case, the whole cryopreservation procedure was applied to somatic embryos (desiccation, freezing, thawing, re-growth). Embryos were then transferred onto shoot growth medium.

After desiccation, water content of embryos was monitored in order to secure the following freezing procedure. As a consequence, some of the batches from the (DO) treatment were missing for several clonal lines, as somatic embryos were preferably used for water content measurements.

\section{In situ field collection}

Preservation of clonal oil palm genetic resources as in situ field collections is the most common strategy. In this case, the preserved germplasm comprises nursery or field planted clonal plants.

Recloning experiments were performed on palms originating from either nursery stage (not yet flowering) or field plantings (palms aged 3-8 years with monitored flowering). As a result, 28 clonal lines were obtained from the recloning of 19 somaplants. The floral phenotype of ramets used as mother palms could be of 3 types: « mantled » somaplants, normal somaplants, or nursery somaplants of undetermined floral phenotype. We have considered the floral phenotype of the recloned ramet of the somaplants from previous plantings of the same clonal line and of the somaplants population from where the ramet originated. From this epigenetic background, 4 different classes of recloned ramets could be differentiated (Table 1 ).

\section{Field monitoring of floral trueness-to- type}

The « mantled » character could be observed with the naked eye, as soon as the first flowering occured, more often after 2 to 3 years in the field. The feminization of male organs (staminodes into pseudocarpels) can be observed on flowers of both sexes. It is worth noting that, especially at early flowerings of young palms, the identification of « mantled» male flowers were difficult, because of their resemblance with androgynous male flowers. In the present study, a careful dissection of flowers has been performed before classification.

Observed flowers were grouped into three different classes (Table 2), depending on the severity of the " mantled » character : normal (N), slightly mantled (SM) or severely mantled (M). Each class usually corresponds to a precise classification of floral parameters (Konan et al., 1995). For simplicity, all the " mantled » palms were grouped in a single class, « mantled » $(\mathrm{M})$.

Regenerant palms originating from the three tested preservation strategies were observed in the field at 3-4 years after planting. Estimation of the frequency of abnormal and normal palms were performed on female flowers only. A given clonal line was recorded as « mantled » if at least one somaplant from this line has generated « mantled » inflorescences (whether slight or severe). 
Table 1 : Characteristics of the various class of ramets selected for recloning in oil palm.

Caractéristiques des différentes classes de vitroplants utilisés pour le reclonage chez le palmier à huile.

\begin{tabular}{lcccc}
\hline Class & $\begin{array}{c}\text { Floral status } \\
\text { of the ramet }\end{array}$ & $\begin{array}{c}\text { Floral status of the } \\
\text { population of ramets }\end{array}$ & $\begin{array}{c}\text { Floral status of the } \\
\text { clonal line of origin }\end{array}$ & $\begin{array}{c}\text { Number of } \\
\text { recloned ramets }\end{array}$ \\
\hline I & Abnormal (AN) & Abnormal (AN) & Abnormal (AN) & 4 \\
II & Normal (N) & Normal (N) & Anormal (AN) & 6 \\
III & Normal (N) & Normal (N) & Normal (N) & 13 \\
IV & Unknown (U) & Unknown (U) & Normal (N) & 5 \\
\hline
\end{tabular}

Table 2 : Description and scoring of the severity of the « mantled » floral abnormality in oil palm adult somaplants.

Description et notation de l'intensité de l'anomalie florale « mantled » observée sur les vitroplants adultes.

\begin{tabular}{cccccc}
\hline Male Flower & Normal & Normal & Normal & Slightly mantled & Mantled \\
\hline Female Flower & Normal & Slightly mantled & Mantled & Mantled & Mantled \\
\hline $\begin{array}{c}\text { Mark of } \\
\text { somaplant }\end{array}$ & $1-1$ & $1-2$ & $1-3$ & $2-3$ & $3-3$ \\
\hline $\begin{array}{c}\text { Floral status of } \\
\text { somaplant }\end{array}$ & Normal (N) & Slightly mantled (SM) & $\begin{array}{c}\text { Severely Mantled } \\
(\mathrm{M})\end{array}$ & $\begin{array}{c}\text { Severely Mantled } \\
\text { (M) }\end{array}$ & $\begin{array}{c}\text { Severely Mantled } \\
(\mathrm{M})\end{array}$ \\
\hline
\end{tabular}

\section{RESULTS}

\section{IN VITRO PRESERVATION OF SOMATIC EMBRYOS}

Regenerated palms originating from embryo lines in vitro cultivated for 2 to 6 years were found to be almost $100 \%$ normal (Figure 1 ).

Embryo cultures aged 6 to 8 years produced $80 \%$ normal somaplants only, and this rate decreased during the following years to reach $75 \%$ after a 14-year cultivation period (Table 3). After 5 years of tissue culture, 16 clonal lines out of $20(80 \%)$ did not produce any abnormal palm. Four clonal lines (20\%) gave palms with abnormal flowers, the abnormality being observed at different dates depending on the line. It is worth noting that clonal line LMC 063 produced abnormal palms as early as the second year of in vitro cultivation. Regenerants palms showing a « mantled » phenotype were observed on clonal lines LMC 152 and LMC 051 in year 3 and 5 respectively, whereas the first abnormal palm generated from clonal line LMC 130 appeared after 5 years of embryo culture.

The 4 clonal lines, which were found abnormal during the first 5 years of in vitro preservation, showed increasing ratios of abnormal palms during the following years : in fact, somaplants produced with clonal line LMC 063 were all abnormal after a 9-year period of somatic embryo culture.

After 10-years of in vitro embryo preservation, somaplants were still found $100 \%$ normal in 10 clonal lines (LMC 009, LMC 022, LMC 044, LMC 074, LMC 158, LMC 159, LMC 161, LMC 167, LMC 172 and LMC 174) from the 16 original lines which were $100 \%$ normal after 5 years. In the 6 remaining clonal lines (normal after 5 years), some « mantled » palms were observed after 6 7 years in LMC 052, LMC 106, LMC 107 and LMC 144, and after $9-10$ years in LMC 026 et LMC 165. Between 11 and 15 years of in vitro culture, none of the planted clones which were initially normal did change phenotype. After 17 years, 3 clonal lines (LMC 009, LMC 022 et LMC 044) were still $100 \%$ normal. 
No increase of the rate of abnormality was noted. This could be due to the duration of the in vitro cultivation period of somatic embryo lines. Ten clonal lines were found to be highly stable after 10 years in the laboratory. When the whole collection (20 lines) was considered, 80 - $85 \%$ of clonal lines remained normal during the first 2 - 5 years of in vitro preservation. During this period, regenerated palms were almost all normal (98-100 \%), with an average abnormality rate of $2 \%$. After year 5 , a decrease in normal clonal lines was clearly observed, with $50 \%$ of lines showing abnormal regenerants. Between year 10 and 13 , almost $45 \%$ of clonal lines were still found normal, with $80 \%$ of somaplants showing normal flowering. After 17 years of in vitro preservation, only $25 \%$ of the original collection of clonal lines were still able to produce normal regenerants.

\section{CRYOPRESERVATION}

Regenerant palms originating out of five of the six tested clonal lines (except LMC 051) were found to be $100 \%$ normal, no matter the treatment applied (Table 4). Even clonal lines LMC 248 and LMC 249 with respectively $6 \%$ and $4 \%$ « mantled » in previous plantings, generated $100 \%$ normal palms in all treatments.

Cryopreservation treatments induced changes in the rate of abnormality. Indeed, in clonal line LMC 051 , while only $71 \%$ of palms originating from the « standard » treatment were found normal, their counterparts originating from « Desiccation Only » and « Desication-LN » treatments showed respectively $87 \%$ and $95 \%$ normal flowerings. However these discrepancies were not statistically significant $\left(\chi^{2}=0.59\right)$. Similarly, the proportion of « mantled » palms originating from standard and DO treatment, respectively $29 \%$ and $13 \%$, were not significantly different $\left.\alpha^{2}=1.49\right)$. Interestingly, the proportion of « mantled » palms generated through the standard protocol is significantly higher (29\%) than the one observed in palms which were cryopreserved through the (DLN) treatment $\left(5 \% ; \chi^{2}=5.38\right)$.

\section{RECLONING FROM SOMAPLANTS}

We found that the floral status of clonal palms produced by the second or third cloning of somaplants depended on the floral phenotype of : i) the recloned ramet itself, ii) the somaplants

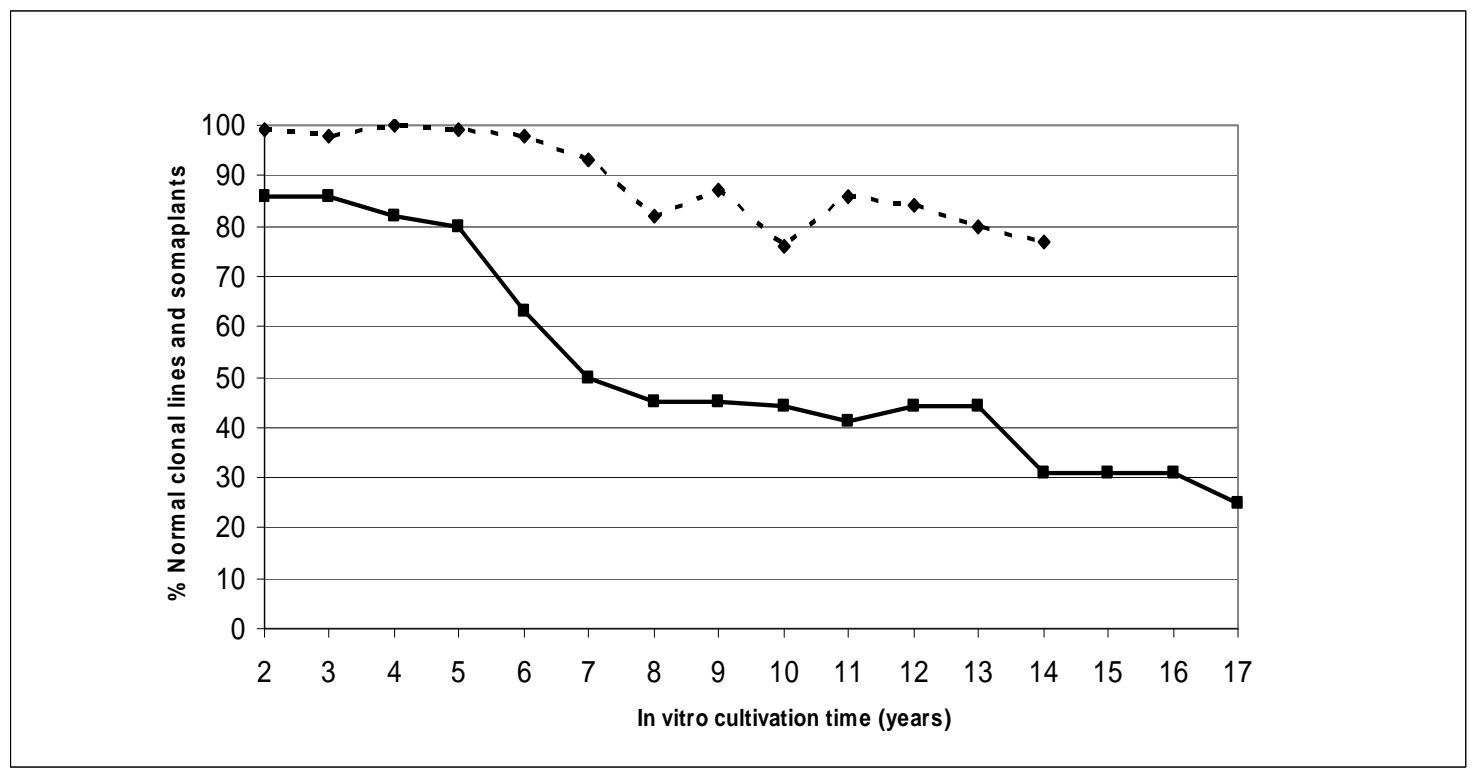

Figure 1 : Changes in floral phenotypes on oil palm clone line and somaplants following the age of in vitro culture.

Evolution du phénotype floral observé sur les clones et vitroplants de palmier à huile en fonction de l'âge des cultures in vitro. 


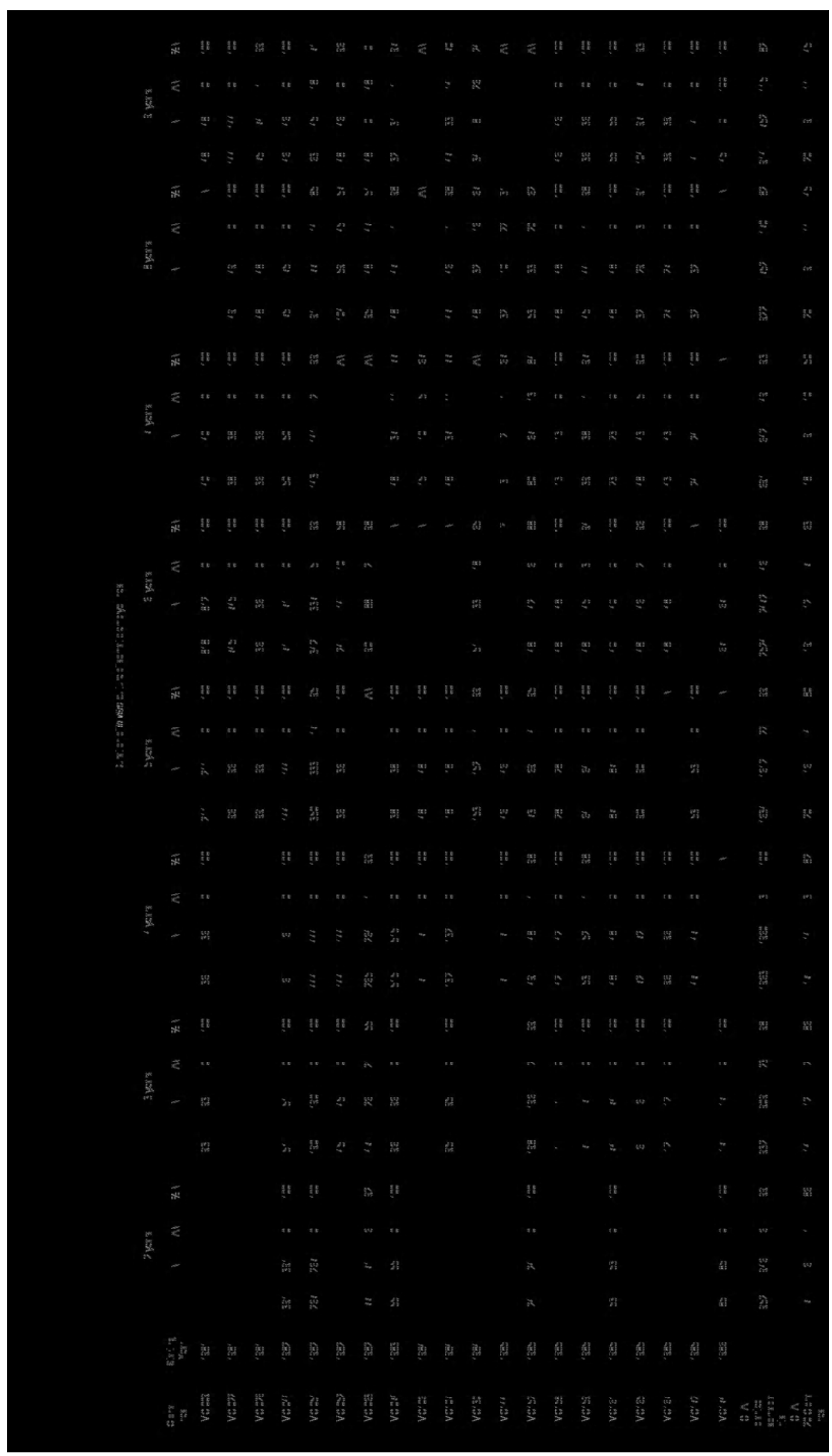

Agronomie Africaine 18 (3) : 187-200 (2006) 


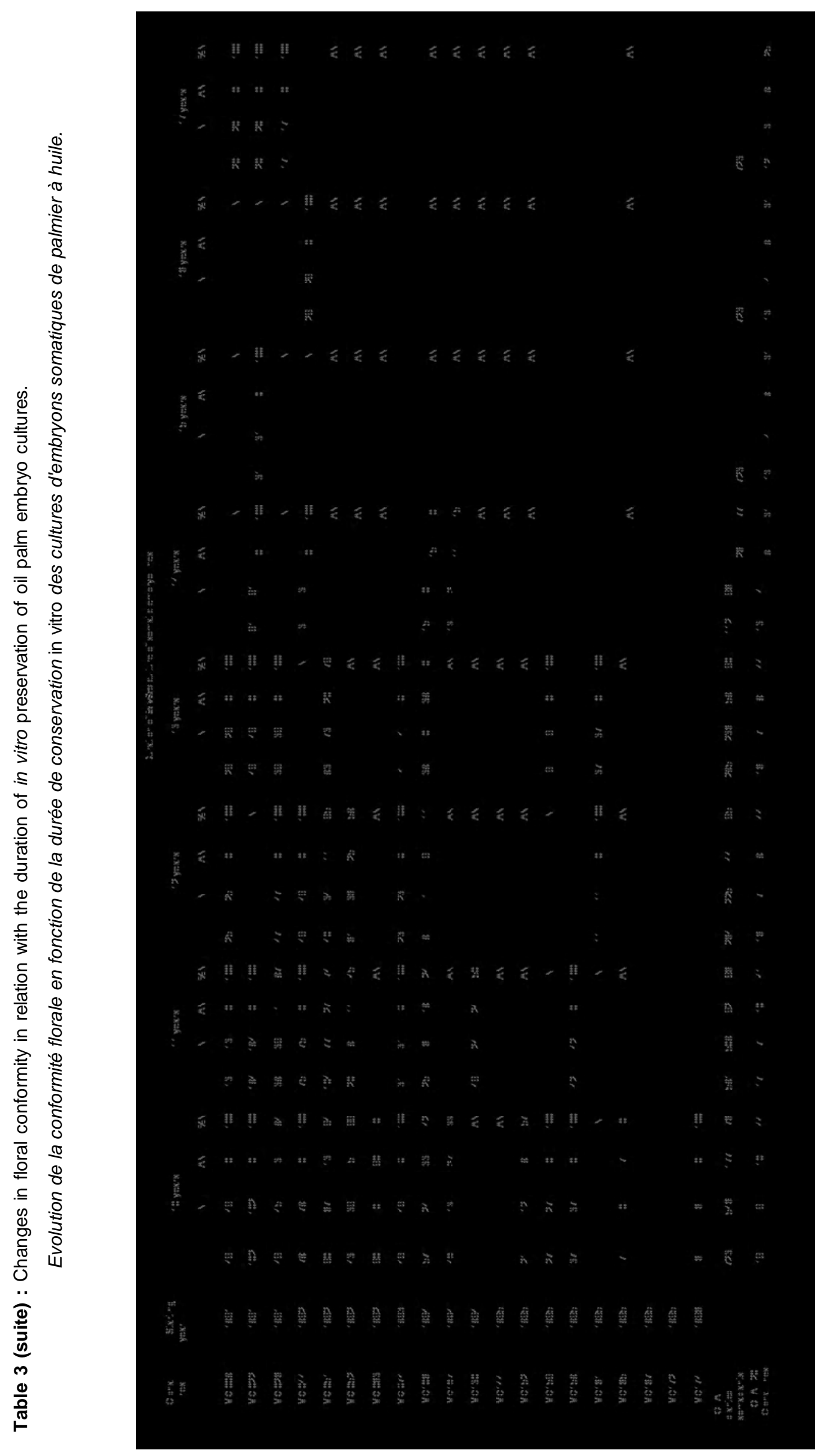


Table 4 : Changes in floral conformity in relation with the oil palm embryo cryopreservation methods.

Evolution de la conformité florale du palmier à huile selon le type de traitement de cryoconservation.

\begin{tabular}{|c|c|c|c|c|c|c|c|}
\hline $\begin{array}{l}\text { Clonal } \\
\text { Line }\end{array}$ & $\begin{array}{c}\text { Floral status } \\
\text { before treatmnent }\end{array}$ & $\begin{array}{c}\text { Preservation } \\
\text { treatments }\end{array}$ & $\begin{array}{c}\text { Flowered } \\
\text { palms }\end{array}$ & $\begin{array}{c}\text { Normal } \\
\text { palms }\end{array}$ & $\begin{array}{c}\text { Mantled } \\
\text { palms }\end{array}$ & $\begin{array}{c}\% \text { Normal } \\
\text { Palms }\end{array}$ & $\begin{array}{c}\% \text { Mantled } \\
\text { palms }\end{array}$ \\
\hline \multirow{3}{*}{ LMC 022} & 11 years in the field & Standard & 25 & 25 & 0 & 100 (a) & 0 \\
\hline & Flowered palms : 3202 & Desiccation Only* & - & - & - & - & - \\
\hline & Normal palms : $100 \%$ & Desiccation + LN & 38 & 38 & 0 & 100 (a) & 0 \\
\hline \multirow{3}{*}{ LMC 051} & 12 years in the field & Standard & 31 & 22 & 9 & 71 (a) & 29 \\
\hline & Flowered palms : 4161 & Desiccation Only & 30 & 26 & 4 & 87 (a) (b) & 13 \\
\hline & Normal palms : $86 \%$ & Desiccation + LN & 39 & 37 & 2 & $95(b)$ & 5 \\
\hline \multirow{3}{*}{ LMC 119} & 4 years in the field & Standard & 25 & 25 & 0 & 100 (a) & 0 \\
\hline & Flowered palms : 202 & Desiccation Only & 27 & 27 & 0 & $100(a)$ & 0 \\
\hline & Normal palms : $100 \%$ & Desiccation + LN & 32 & 32 & 0 & $100(a)$ & 0 \\
\hline \multirow{3}{*}{ LMC 242} & 4 years in the field & Standard & 28 & 28 & 0 & 100 (a) & 0 \\
\hline & Flowered palms : 206 & Desiccation Only & 48 & 48 & 0 & $100(a)$ & 0 \\
\hline & Normal palms : $100 \%$ & Desiccation + LN & 1 & 1 & 0 & 100 (a) & 0 \\
\hline \multirow{3}{*}{ LMC 248} & 4 years in the field & Standard & 31 & 31 & 0 & 100 (a) & 0 \\
\hline & Flowered palms : 376 & Desiccation Only* & - & - & - & - & - \\
\hline & Normal palms : $94 \%$ & Desiccation + LN & 41 & 41 & 0 & $100(a)$ & 0 \\
\hline \multirow{3}{*}{ LMC 249} & 3 years in the field & Standard & 14 & 14 & 0 & 100 (a) & 0 \\
\hline & Flowered palms : 280 & Desiccation Only* & - & - & - & - & - \\
\hline & Normal palms : $96 \%$ & Desiccation + LN & 30 & 30 & 0 & $100(a)$ & 0 \\
\hline \multirow{3}{*}{\multicolumn{2}{|c|}{ Total 6 clonal lines }} & Standard & 154 & 145 & 9 & $94(a)$ & 6 \\
\hline & & Desiccation Only & 105 & 101 & 4 & $96(a)(b)$ & 4 \\
\hline & & Desiccation + LN & 191 & 179 & 2 & 99 (b) & 1 \\
\hline
\end{tabular}

Percentage values followed by the same letter (a), (b) are not significantly different

Les pourcentages suivis de la même lettre ne sont pas significativement différents

* Not applicable for not enough embryos cultures

from previous plantings of the same clonal line and iii) of the population of somaplants from which the ramet originated.

We have recloned 4 abnormal ramets belonging to Class I (abnormal ramet, abnormal population, abnormal clonal line). Results presented in Table 5 show that, in this case, the generated clonal lines were all « mantled », with a very high percentage of abnormal palms (60 to $100 \%$ ).

When ramets from Class III (normal ramet, normal population, abnormal clonal line) were recloned, trueness-to-type could not be guaranteed. Indeed, from 6 recloned ramets, only $4(66 \%)$ gave $100 \%$ normal offspring, while 2 (33\%) generated clonal populations has $5 \%$ « mantled » palms.

The recloning of ramets from Class IV (normal ramet, normal population, normal clonal line) seems to be the safest strategy in terms of genetic stability. In fact, from 13 recloned ramets (including 2 ramets already originating from reclonings), no « mantled » palms were detected among the offspring.

Our results clearly show that rates of somaclonal variants in regenerants palms from a 2nd and even a 3rd cloning operation rely on the floral status of the ramet used as the source of explants. The presence of variants in one of the components of the triplet (ramet/population/ clonal line) was sufficient to jeopardize the recloning operation.

The age of the recloned ramet at the time of sampling was also of paramount importance. Indeed, the « blind » recloning of Class $V$ ramets at the nursery stage (thus without any information on their future floral status) appeared to be a very risky strategy in terms of floral conformity. From 5 ramets recloned from clonal line LMC 010, 44 \% (2 palms) generated abnormal somaplants, although at very different rates (2\% and $92 \%$ ). 
Table 5 : Impact of recloning on the floral conformity of oil palm regenerants.

Impact du reclonage sur la conformité florale des régénérants de palmier à huile.

\begin{tabular}{|c|c|c|c|c|c|c|c|c|c|}
\hline \multirow{2}{*}{$\begin{array}{l}\text { Original } \\
\text { clonal line of } \\
\text { ramet }\end{array}$} & \multirow{2}{*}{$\begin{array}{l}\text { Clonal line } \\
\text { resulting of } \\
\text { Recloning }\end{array}$} & \multirow{2}{*}{$\begin{array}{l}\text { Class of } \\
\text { recloned } \\
\text { ramet }\end{array}$} & \multicolumn{3}{|c|}{ Floral Status } & \multicolumn{4}{|c|}{ Floral status of somaplants generated by recloning } \\
\hline & & & $\begin{array}{c}\text { Utilised } \\
\text { ramet }\end{array}$ & $\begin{array}{l}\text { Population } \\
\text { of origin }\end{array}$ & $\begin{array}{l}\text { Clonal line } \\
\text { of origin }\end{array}$ & $\begin{array}{c}\text { New recloned } \\
\text { flowering soma } \\
\text { plants }\end{array}$ & Normal & Abnormal & $\%$ Abnormal \\
\hline LMC 017 & LAB 257 & I & AN & AN & AN & 5 & 2 & 3 & 60 \\
\hline LMC 073 & LAB 282 & I & $\mathrm{AN}$ & AN & $\mathrm{AN}$ & 100 & 11 & 89 & 89 \\
\hline LMC 088 & LAB 256 & I & AN & AN & AN & 69 & 0 & 69 & 100 \\
\hline BC 062 & LAB 255 & $\mathrm{I}$ & $\mathrm{AN}$ & $\mathrm{AN}$ & $\mathrm{AN}$ & 24 & 0 & 24 & 100 \\
\hline \multicolumn{6}{|c|}{ Total nbr of palms } & 198 & 13 & 185 & 93 \\
\hline \multicolumn{6}{|c|}{ Total new clones } & 4 & 0 & 4 & 100 \\
\hline LMC 036 & LAB 206 & III & $\mathrm{N}$ & $\mathrm{N}$ & AN & 144 & 129 & 15 & 10 \\
\hline LMC 051 & LAB 306 & III & $\mathrm{N}$ & $\mathrm{N}$ & $\mathrm{AN}$ & 38 & 38 & 0 & 0 \\
\hline LMC 051 & LAB 334 & III & $\mathrm{N}$ & $\mathrm{N}$ & AN & 2 & 2 & 0 & 0 \\
\hline LMC 063 & LAB 317 & III & $\mathrm{N}$ & $\mathrm{N}$ & $\mathrm{AN}$ & 43 & 36 & 7 & 16 \\
\hline BC 068 & LAB 380 & III & $\mathrm{N}$ & $\mathrm{N}$ & $\mathrm{AN}$ & 155 & 153 & 0 & 0 \\
\hline BC 068 & LAB 386 & III & $\mathrm{N}$ & $\mathrm{N}$ & AN & 58 & 58 & 0 & 0 \\
\hline \multicolumn{6}{|c|}{ Total nbr of palms } & 440 & 416 & 22 & 5 \\
\hline \multicolumn{6}{|c|}{ Total new clones } & 6 & 4 & 2 & 33 \\
\hline LMC 009 & LAB 196 & IV & $\mathrm{N}$ & $\mathrm{N}$ & $\mathrm{N}$ & 16 & 16 & 0 & 0 \\
\hline LMC 009 & LAB 197 & IV & $\mathrm{N}$ & $\mathrm{N}$ & $\mathrm{N}$ & 138 & 138 & 0 & 0 \\
\hline LMC 021 & LAB 316 & IV & $\mathrm{N}$ & $\mathrm{N}$ & $\mathrm{N}$ & 2 & 2 & 0 & 0 \\
\hline LMC 022 & LAB 376 & IV & $\mathrm{N}$ & $\mathrm{N}$ & $\mathrm{N}$ & 48 & 48 & 0 & 0 \\
\hline LMC 022 & LAB 396 & IV & $\mathrm{N}$ & $\mathrm{N}$ & $\mathrm{N}$ & 28 & 28 & 0 & 0 \\
\hline LMC 032 & LAB 384 & IV & $\mathrm{N}$ & $\mathrm{N}$ & $\mathrm{N}$ & 1 & 1 & 0 & 0 \\
\hline LMC 058 & LAB 283 & IV & $\mathrm{N}$ & $\mathrm{N}$ & $\mathrm{N}$ & 1 & 1 & 0 & 0 \\
\hline LMC 072 & LAB 381 & IV & $\mathrm{N}$ & $\mathrm{N}$ & $\mathrm{N}$ & 48 & 48 & 0 & 0 \\
\hline LMC 072 & LAB 382 & IV & $\mathrm{N}$ & $\mathrm{N}$ & $\mathrm{N}$ & 24 & 24 & 0 & 0 \\
\hline LMC 077 & LAB 408 & IV & $\mathrm{N}$ & $\mathrm{N}$ & $\mathrm{N}$ & 35 & 35 & 0 & 0 \\
\hline $\begin{array}{l}\text { LMC } 119 \\
\text { LMC } 010\end{array}$ & LAB 409 & IV & $\mathrm{N}$ & $\mathrm{N}$ & $\mathrm{N}$ & 7 & 7 & 0 & 0 \\
\hline $\begin{array}{l}\text { (LAB 200) } \\
\text { LMC } 010\end{array}$ & LAB $479 *$ & IV & $\mathrm{N}$ & $\mathrm{N}$ & $\mathrm{N}$ & 26 & 26 & 0 & 0 \\
\hline (LAB 201) & LAB $480 *$ & IV & $\mathrm{N}$ & $\mathrm{N}$ & $\mathrm{N}$ & 12 & 12 & 0 & 0 \\
\hline \multirow{2}{*}{\multicolumn{6}{|c|}{$\begin{array}{l}\text { Total nbr of palms } \\
\text { Total new clones }\end{array}$}} & 386 & 386 & 0 & 0 \\
\hline & & & & & & 13 & 13 & 0 & 0 \\
\hline LMC 010 & LAB 200 & $\mathrm{~V}$ & $\mathrm{U}$ & $\mathrm{U}$ & $\mathrm{N}$ & 100 & 100 & 0 & 0 \\
\hline LMC 010 & LAB 201 & V & $\mathrm{U}$ & $\mathrm{U}$ & $\mathrm{N}$ & 8 & 8 & 0 & 0 \\
\hline LMC 010 & LAB 202 & $\mathrm{~V}$ & $\mathrm{U}$ & $\mathrm{U}$ & $\mathrm{N}$ & 100 & 96 & 2 & 2 \\
\hline LMC 010 & LAB 203 & V & $\mathrm{U}$ & $\mathrm{U}$ & $\mathrm{N}$ & 129 & 129 & 0 & 0 \\
\hline LMC 010 & LAB 204 & $\mathrm{~V}$ & $\mathrm{U}$ & $\mathrm{U}$ & $\mathrm{N}$ & 48 & 2 & 44 & 92 \\
\hline \multirow{2}{*}{\multicolumn{6}{|c|}{$\begin{array}{l}\text { Total nbr of palms } \\
\text { Total new clones }\end{array}$}} & 385 & 335 & 46 & 12 \\
\hline & & & & & & 5 & 3 & 2 & 44 \\
\hline
\end{tabular}

These new clones have undertaken 3 in vitro cloning (reclonings of LMC10 line).

Abbreviations : $\mathrm{N}$ - Normal female flowering, AN - Abnormal female flowering

\section{DISCUSSION}

\section{IN VITRO PRESERVATION OF SOMATIC EMBRYOS}

Results show that the cultivation of oil palm embryogenic lines on prolonged periods induced an increase in the proportion of « mantled » clonal lines and somaplants, thus confirming observations made by Corley et al. (1986). However this increase could not be considered as a general tendency for all clonal lines, as large discrepancies between lines were observed. Clonal lines could be classed in 3 different categories:
- clonal lines with high in vitro stability, which did not generate any somaclonal variant, even after 17 years of in vitro cultivation as embryo lines ;

- clonal lines showing early signs of instability: « mantled » abnormality was detected after a few years of in vitro preservation and then regularly increased with preservation time;

- clonal lines showing late signs of instability: « mantled » abnormality was detected after a few years (> 5) of in vitro preservation.

Various hypothesis have been set forth concerning the biochemical and molecular origin of the « mantled » somaclonal variation in oil palm (Soh, 1986 ; Rao and Donough, 1990 ; Marmey et al., 1991 ; Morcillo et al., 2000 ; 
Jaligot et al., 2000 ; Tregear et al., 2002 ; Rival et al., 2003 ; Rival and Parveez, 2004).

Among these hypothesis, the implication of cytokinins, a family of plant growth regulators widely used in tissue culture, is worth confronting with our results. Besse et al. (1992, 1994), then Jones et al. (1995) have showed that the occurrence of the « mantled » abnormality could be related to changes in endogenous cytokinin metabolism. Indeed, FGC (Fast Growing Calluses) which generated $100 \%$ mantled palms were found to have a lower cytokinin content than NCC (Nodular Compact Calluses) resulting in less than $5 \%$ mantled palms. It is thus possible that successive transfers of somatic embryos deriving from calluses on a hormone free medium through long period could induce a progressive dilution of the original concentration of endogenous cytokinins, thus resulting in the generation of variant palms. Discrepancies between clonal lines could be explained by differences in the original concentration of cytokinins in embryo lines and by differences in cytokinins metabolism.

In Côte d'Ivoire, more than 1000 ha of clonal material from 230 clonal lines have been planted for genetic and agronomic performance tests carried out since 1985 (Durand-Gasselin et al., 1993 ; Konan et al., 1997 ; Duval et al., 1997 ; Cochard et al., 1999). Field assessment of floral conformity showed that the overall incidence of the « mantled » abnormality was within the 5$10 \%$ range, with $40-50 \%$ of clonal lines affected by somaclonal variation (Durand-Gasselin et al., 1993 ; Konan et al., 1995).

This rate of abnormality agreed with that observed in our study for palms originating form embryo cultures in vitro preserved for 7 years. Thus, if all embryo lines older than 6 years were discarded and if only palms originating from younger cultures were planted, the proportion of normal clonal lines would reach 60-90 \%, with only $1-2 \%$ of « mantled » palms. It is clear that a preservation strategy based on the in vitro preservation of somatic embryo lines could be acceptable only for short term purposes.

\section{CRYOPRESERVATION OF SOMATIC EMBRYOS}

Our study has enabled an assessment of the impact of the simplified procedure for cryopreservation of oil-palm somatic embryos
(Dumet et al., 1993a,b) on the floral conformity of the regenerated material. The advantages of cryopreservation have been described by several authors (Berthaud, 1997 ; Engelmann and Takagi, 2000). In oil-palm, our results show that the utilization of the whole cryopreservation procedure did not have a detrimental impact on the floral conformity of regenerated palms. Our findings confirm results published on strawberry and cassava, showing that plants generated from cryopreserved meristems were not morphologically different from their noncryopreserved counterparts (Kartha et al., 1980 ; Bajaj, 1983). Similar results have been obtained after cryopreservation of Musa embryogenic suspension cultures (Cote et al., 2000). In Picea abies and Hevea brasiliensis, an increase in the regeneration potential of embryogenic calluses after cryopreservation has even been described (Bercetche et al., 1990 ; Engelmann et al., 1997). These authors suggested that non-embryogenic tissues may have been preferentially destroyed during the cryopreservation procedure.

For oil palm, the cryopreservation protocol described by Dumet et al. (1993a, b) is based on two distinct steps : desiccation and freezing. Each of these two treatments did not induce any significant change in the floral conformity of offsprings. For one clonal line, the cryopreservation procedure was even found to decrease the rate of abnormal flowering. These results raises interesting questions about the selective pressure exerted on normal/abnormal cells by the cryopreservation protocol. It will be worth implementing a series of experiments in order to confirm that cells giving rise to abnormal embryos are more sensitive than normal ones to the cryopreservation procedure.

\section{RECLONING FROM SOMAPLANTS}

Our data have clearly shown that the presence of variants in one of the components of the triplet (ramet/population/ clonal line) is sufficient for jeopardizing the recloning operation. This important result, when combined with the existence of a reversion towards normal phenotype with age (Durand-Gasselin et al., 1993, Konan et al., 1995 ; Duval et al., 1997) paves the way for new research on the molecular determinism of the «mantled » somaclonal variation in oil palm. 
Indeed, recent results have highlighted the role of DNA methylation in the occurrence of the « mantled » variation (Jaligot et al., 2000 ; Jaligot et al., 2004 ; Rival and Parveez, 2004). It will be worth investigating the DNA methylation status of plant material throughout the recloning protocol, and trying to correlate this status with the floral phenotype of regenerants. The epigenetic background of each recloned ramet, as reflected by the phenotypic status of the triplet (ramet/population/clonal line) should be explored with a DNA methylation perspective.

A preservation strategy based on the recloning of assessed somaclones can be acceptable in terms of genetic stability, provided that the selected ramet is deriving from a $100 \%$ normal background (ramet/population/clonal line).

\section{CONCLUSION}

Three different approaches (namely : re-cloning of clonal material, in vitro preservation, and cryopreservation) for the preservation of oil palm (Elaeis guineensis Jacq.) clonal genetic resources and their respective impact on the induction of the « mantled » somaclonal variation were assessed.

Results show that the cultivation of oil palm embryogenic lines on prolonged periods induced an increase in the proportion of « mantled » clonal lines and somaplants. It is clear that a preservation strategy based on the in vitro preservation of somatic embryo lines could be acceptable only for short term purposes $(<6$ years). Nevertheless, discarding embryo cultures older than 6 years in commercial laboratories will have a significant impact on the average rate of « mantled » abnormality.

The utilization of the whole cryopreservation procedure did not have a detrimental impact on the floral conformity of regenerated palms. This strategy is thus considered as suitable for the long term preservation of clonal oil palm genetic resources.

A preservation strategy based on the recloning of assessed somaclones can be acceptable in terms of genetic stability, provided that the selected ramet is deriving from a $100 \%$ normal background (ramet/population/clonal line).

\section{REFERENCES}

Bajaj (Y. P. S.). 1983. Cassava plants from meristem cultures freeze-preserved for three years. Fields Crops Research 7 (3) : $161-167$

Bercetche (J.), (M.) Galerne and (J.) Dereuddre. 1990. Greater capacity for regeneration of plantlets from embryogenic callus of Picea abies after freezing in liquid nitrogen. C. R..Acad. Sci. Paris, Série 3, 310 (8) : 357 - 362.

Berthaud (J.). 1997. Strategies for conservation of genetic resources in relation with their utilization. Euphytica $96: 1$ - 12 - P 264.

Besse (I.), (J. L.) Verdeil, (Y.) Duval, (B.) Sotta (R.) Maldiney and (C.) Miginiac. 1992. Oil palm (Elaeis guineensis Jacq.) clonal fidelity : endogenous cytokinins and indoleacetic acid in embryogenic callus cultures. J. Experim. Bot. 43 : 983 - 989.

Besse (I.), (T.) Beule, (J. L.) Verdeil and (Y.) Duval. 1994. Study of endogenous cytokinins levels associated with an anomaly in floral morphogenesis of Elaeis. In : Teisson C (eds) In vitro cuture of tropical plants. CIRAD, Montpellier (France) : 37 - 41.

Chabrillange (N.), (F.) Aberlenc-Bertossi, (M.) Noirot, (Y.) Duval and (F.) Engelmann. 2000. Cryopreservation of oil palm embryogenic suspensions. In : Engelmann F. and Tagaki $\mathrm{H}$ (eds). Cryopreservation of tropical germplasm : Current research progress and applications. Tsukuba (Japan) : IRCAS, Rome (Italy), IPGRI : 172 - 177.

Cochard (B.), (T.) Durand-Gasselin, (P.) Amblard, (E.) Konan et (S.) Gogor. 1999. Production d'huile des clones de palmier à huile à l'âge adulte. In : Proceedings of 1999 PIPOC Congress, Kuala Lumpur (Malaysia). Kuala Lumpur, PIPOC : 12 - 22.

Corley (R. H. V.), (C. H.) Lee, (I. H.) Law and (C. Y.) Wong. 1986. Abnormal flower development in oil palm clones. Planter $62: 233-240$

Corley (R. H. V.), (T.) Boonrak, (C. R.) Donough, (S.) Nelson and (F.) Dumortier. 1995. Yield of oil palm clones in different environments. In : Proceedings of 1993 ISOPB International Symposium on Recent Development in Oil Palm Tissue Culture and Biotechnology, (V. Rao, LE. Henson and N. Rajanaidu, eds). Int. Soc. Oil Palm Breeding. Kuala Lumpur (Malaysia) : 145 - 157. 
Corley (R. H.). 2003. Oil palm : a major tropical crop. Burotrop, Bulletin 19, $2003: 5$ - 8.

Cote (F. X.), (O.) Goue, (R.) Domergue, (B.) Panis and (C.) Jenny. 2000. In-Fields behaviour of banana plants (Musa AA sp.) obtained after regeneration of cryopreserved embryogenic cell suspensions. CryoLetters 21, 19 - 24.

Dumet (D.), (F.) Engelmann, (N.) Chabrillange and (Y.) Duval. 1993a. Cryopreservation of oil plam (Elaeis guineensis Jacq.) somatic embryos involving a desiccation step. Plant Cell Reports 12 : 352 - 355.

Dumet (D.), (F.) Engelmann, (N.) Chabrillange, (Y.) Duval and (J.) Dereuddre. 1993b. Importance of sucrose for the acquisition of tolerance to desiccation and cryopreservation of oil palm somatic embryos. Cryo-Letters $14: 243$ - 250.

Durand-Gasselin (T.), (Y.) Duval, (L.) Baudouin, (A. B.) Maheran, (K. E.) Konan and (J. M.) Noiret. 1993. Description and degree of the mantled flowering abnormality in oil palm (Elaeis guineensis Jacq.) clones produced with ORSTOM-CIRAD procedure. In : Proceedings of 1993 ISOPB International Symposium on Recent Development in Oil Palm Tissue Culture and Biotechnology, (V. Rao, LE. Henson and N. Rajanaidu, eds). Int. Soc. Oil Palm Breeding. Kuala Lumpur (Malaysia) : 48 - 63.

Durand-Gasselin (T.), (C.) Cochard, (P.) Amblard et $(\mathrm{H}$.) De Franqueville. 2002. Un regard sur quarante ans d'amélioration génétique du palmier à huile (Elaeis guineensis Jacq.) et son impact sur la filière. Le Sélectionneur Français 53 : ISSN 0374 - 1621.

Duval (Y.), (T.) Durand-Gasselin, (K. E.) Konan et (C.) Pannetier. 1988. Multiplication végétative du palmier à huile (Elaeis guineensis Jacq.) par culture in vitro: Stratégies et résultats. Oléag. 43 (2) : 29 - 44.

Duval (Y.), (F.) Engelmann and (T.) DurandGasselin. 1995. Somatic embryogenesis in oil palm (Elaeis guineensis Jacq.). In : Somatic embryogenensis and Synthetic Seed I., Biotechnology in Agriculture and Forestry, Y P S Bajaj (eds), Springer Verlag $30: 335-352$.

Duval (Y.), (P.) Amblard, (A.) Rival, (K. E.) Konan, (S.) Gogor and (T.) Durand-Gasselin. 1997. Progress in oil palm tissue culture and clonal performance in Indonesia and the Côte d'Ivoire. International Planters Conference, Kuala Lumpur, 21-22 May 1997. Kuala Lumpur (Malaysia), PORIM : 291 - 307.
Engelmann (F.), (Y.) Duval et (J.) Dereuddre. 1985. Survie et prolifération d'embryons somatiques de palmier à huile (Elaeis guineensis Jacq.) après congélation dans l'azote liquide. C.R. Acad. Sci. Paris, Série 3, Vol 301 (3) : 111 - 116.

Engelmann (F.), (N.) Lartaud, (N.) Chabrillange, (M. P.) Carron and (H.) Étienne. 1997. Cryopreservation of embryogenic calluses of two commercial clones of Hevea brasiliensis. Cryo-Letters 18, 107 - 116.

Engelmann (F.) and (H.) Takagi. 2000. Cryopreservation of Tropical Plant Germsplam - Current Research Progress and Applications. JIRCAS, Tsukuba and IPGRI, Rome.

Jaligot (E.), (A.) Rival, (T.) Beule, (S.) Dussert and (J. L.) Verdeil. 2000. Somaclonal variation in oil palm (Elaeis guineensis Jacq.) : the DNA methylation hypothesis. Plant Cell Reports $19: 684$ - 690 .

Jaligot (E.), (T.) Beulé, (F. C.) Baurens, (N.) Billote and (A.) Rival. 2004. MSAP screening for differentially methylated markers associated with the « mantled » somaclonal variation in oil palm (Elaeis guineensis Jacq.). Genome 47 : 224 - 228.

Jones (L. H.), (D. E.) Hanke and (C. J.) Euwens. 1995. An Evaluation of the Role of Cytokinins in the Development of Abnormal Inflorescences in Oil Palms (Elaeis guineensis Jacq.) Regenerated from Tissue Culture. J. Plant Growth Regul 14 : 135 - 142.

Kartha (K. K.), (N. L.) Leung and (K.) Pahl. 1980. Cryopreservation of strawberry meristems and mass propagation of plantlets. J. Amer. Soc. Hort. Sci. 105 (4) : 481 - 184.

Konan (K. E.), (T.) Durand-Gasselin, (Y.) Duval et (B.) Kouamé. 1995. Anomalie de la morphogenèse florale (anomalie mantled) observée chez les plants de palmier à huile (Elaeis guineensis Jacq.) obtenus par embryogenèse somatique. Etude de la réversion vers un phénotype normal des plants non-conforme. In : $5^{\mathrm{e}}$ Journées Scientifiques du Réseau AUPELF/UREF «Biotechnologie végétales » 13 au 15 Décembre 1995, Dakar (Sénégal). Paris, ESTEM : 26 - 46.

Konan (K. E.), (T.) Durand-Gasselin, (B.) Cochard, (A.) Rival et (B.) Kouamé. 1997. Caractéristiques de production des vitroplants de palmier à huile plantés en Côte d'Ivoire en conditions agro- 
industrielles. In : $6^{\text {e }}$ Journées Scientifiques du Réseau AUPELF/UREF «Biotechnologie végétales », 30 Juin au 03 Juillet 1997, Orsay (France). Paris, ESTEM : 159 - 167.

Konan (K. E.), (T.) Durand-Gasselin, (Y. T.) Kouadio and (A.) Rival. 2005. A modelling approach of the in vitro conversion of palm (Elaeis guineensis Jacq.) somatic embryos. Plant Cell Tissue and Organ Culture 84 : 99 - 112

Marmey (P. H.), (I.) Besse et (J. L.) Verdeil. 1991. Mise en évidence d'un marqueur protéique différenciant deux types de cals de même clone chez le palmier à huile (Elaeis guineensis Jacq.). C. R. Acad. Sci. Paris, $\mathrm{t}$ 313, Série III : 333 - 338.

Meunier (J.), (L.) Baudouin, (B.) Nouy et (J. M.) Noiret. 1988. Estimation de la valeur des clones de palmier à huile. Oléag. $30: 5$ - 8.

Noiret (J. M.). 1981. Application de la culture in vitro à l'amélioration et à la production de matériel clonal chez le palmier à huile. Oléag. 36 : 123 - 125.

Pannetier (C.), (P.) Arthuis et (D.) Liévoux. 1981 Néoformation de jeunes plants de Elaeis guineensis à partir de cals primaires obtenus sur fragments foliaires cultivés in vitro. Oléag. 36 (3) : 119 - 122.

Paranjothy (K.), (O.) Rohani, (A. H.) Tarmizi, (C. S.) Tan and (C. C.) Tan. 1989. Current status and strategies of oil palm tissue culture research. In : PORIM Int. Palm Oil Development Conferenec, Kuala Lumpur, PORIM : 109 - 121.

Rao (V.) and (C. R.) Donough. 1990. Preliminary evidence of a genetic cause for the floral abnormalities in some oil palm ramets. Elaeis 2 : 199 - 207.

Rival (A.), (F.) Aberlenc-Bertosi, (F.) Morcillo, (T.) Tregear, (J. L.) Verdeil, (T.) Durand-
Gasselin, (K. E.) Konan et (B.) Kouamé 1998. Multiplication clonale du palmier à huile par embryogenèse somatique du palmier à huile (Elaeis guineensis Jacq.)Programme de recherche lié au transfert d'échelle. Cahiers Agric. 7: 492 - 498.

Rival (A.), (J.) Tregear, (E.) Jaligot, (F.) Morcillo, (F.) Aberlenc-Bertosi, (N.) Billotte, (F.) Richaud, (T.) Beule, (A.) Borgel and (Y.) Duval. 2003. Biotechnology of the oil palm. In : Plant Genetic Engineering Vol ., Improvement of Commmercial Plants II, P. K. Jawal and R. p. Singh (eds), SCl Tech Publising LLC, Houston, USA : 261 - 318.

Rival (A.) and (M.) Parveez. 2004. Elaeis guineensis, Oil palm. In Biotechnology of Fruit and Nut Crops. R. LITZ (eds). Biotechnology in Agriculture Series $n^{\circ} 29, C A B I$ Publishing, Wallingford, UK : $1113-143$

Soh (A. C.). 1986. Expeted yield increase with selected oil palm clones from current seedling material. Oléag. 41 (2) : 51 - 56.

Tregear (J.), (F.) Morcillo, (F.) Richaud, (A.) Berger, (S.) Rajinder, (S. C.) Chea, (C.) Hartmann, (A.) Rival and (Y.) Duval. 2002. Characterisation of a defensin gene expressed in oil palm influorescences: induction during tissue culture and possible association with epigenetic somaclonal variation events. J. Experim. Bot. 53 : 1387 - 1396.

Wong (G.), (C. C.) Tan and (A. C.) Soh. 1996. Large scale propagation of oil palm clones: Experience to date. Acta Hort. $447: 649-658$

Wooi (K. C.). 1990. Oil palm (Elaeis guineensis Jacq.) : Tissue Culture and Micropropagation. In : Y P S Bajaj (eds) Biotechnology in Agriculture and Forestry, Legumes and Oilseed Crops I. Springer-Verlag 10 : $569-592$. 